\title{
LITERATURA
}

A FOLKLÓR

UDC 80

DOI: $10.24045 / f v .2017 .1 .4$

\section{IMAGE OF THE QUEEN IN NOVEL BY S. TOWNSEND "THE QUEEN AND ME"}

\author{
A. I. Dzyubenko \\ Ya. A. Strezeva
}

\author{
Candidate of Philological Sciences \\ assistant professor \\ student \\ Southern Federal University \\ Rostov-on-Don, Russia
}

\begin{abstract}
The article touches upon the narrative ways of alternation of the sociocultural stereotype that has long been rooted in the minds of communicants perceiving the Queen of the United Kingdom purely as a stern, strong-willed politician depriving her of traits common to life. However, this stereotype is broken by the story that came under the pen of the English writer, Sue Townsend, who used intriguing methods to help the readers picture this situation vividly. The Queen and the Royal family have to survive in very intricate circumstances and every member of the family behaves differently in this challenging situation. The fictional discourse under analysis portrays the Queen in a most unexpected way worthy of investigation.

Keywords: narration; narrative structure; ludicrous and instructive piece of fiction; rhetorical question.
\end{abstract}

The institution of monarchy has long been serving as a vehicle of not only ruling different bodies within the structure of a state, but also as a living symbol of some stability, long-lasting tradition and inviolability. It has also turned into one of the sociocultural stereotypes that exit about the British nation. All these points are skillfully opposed by the whole narrative structure of the novel "The Queen and I" by S. Townsend.

The stereotypes can be formed by the characteristics one nation has of the other, of the culture of another nation and of all phenomena that make up the conceptional base of the latter: norms of verbal and non-verbal behavior, cognitive categories, prejudice and superstitions, moral and etiquette rules, customs and traditions [2, c. 43]. Among the classes of stereotypes the researchers tend to distinguish among verbal behavior; non-verbal behavior (gestures, body language); national character and other nations' ideas of it; social situations and the behavior in them; the peculiarities of the way of 
life and routine of a particular nation; cuisine; religion and national rites $[1$, c. 392].

The driving pertinent question that arises while the reader plunges into the plot of it centers around the idea if the life of the Queen can anyhow be made equal to the ordinary people's one and if there can be any peaceful ways to alter the lives of present monarchs. That was the point of Sue Townsend who managed to find intricate narrative methods and positive answers to the questions mentioned. Her work is both ludicrous and instructive piece of fiction in which the Republicans chaired by Jack Barker took over the power of Great Britain and demolished the monarchy. The Queen had to move to the two-bedroomed semi in Hellebore Close (known as Hell Close) with her family. She had to learn what it is like to be an ordinary and poor person.

During her life in the Hell Close, she was too meet a lot of difficulties and of course, the Queen was not ready for them. At first, she was devastated about her moving to the new place: «The Queen was tired - she had never been so tired. She could not make any decisions. She wanted to retire to her room in Buckingham Palace, where her nightgown would be laid out. She wanted to slide between the linen sheets and drop her head onto the soft pillows and sleep for ever, or until somebody brought the tea tray in the morning» [3, p. 18]. Furthermore, she got irritated by her premises and neighbors as she encountered constant misunderstanding among them (starting with phonological difficulties they had while talking to the ex-Queen and ending with too shabby conditions she was to have dwelling in Hell Close). Being a ruler she should have known that the level of education was low in certain districts of the country but facing these domestic grave problems she forgot all the widely accepted facts and had to go through them herself. She is portrayed as a fighter who doesn't lose the inner power even feeling humiliation and sarcasm aimed at her. The former royal could not believe that it was happening to her and ironically this situation "nonsense" hoping that soon it would come to an end.

The Queen had to do many things she was not used to in the Buckingham Palace: she had to handle money matters, to run the house, to get food and allowances. Above all that, she had to walk the dog named Harris in such frosty weather that when her breath puffed out it was white and visible in front of her: «She put on a coat on over her nightdress and cardigan and tried to open the door. It was extraordinarily difficult. True, it was years since she'd opened the front door of any house» [3, p. 47].

Furthermore, she had troubles with dressing by herself: «How very awkward it was to dress oneself, how fiddly buttons were! Why did zips stick so? How on earth did one choose what went with what?» [3, p. 47]. In other words, the narration illustrates the evolution of a stern politician and a ruler with the nerves of steel into an ordinary, soft-hearted, fragile woman who is to hope for no one's help and worthy of sympathy of the least educated people she has ever met. «The Queen and I» provokes deep thinking of a 
problem that is worded by the Queen herself in a form of a rhetorical question «How did one manage?». The question is repeated several times in various parts of the narration: «There is so much to do thought the Queen. So many tasks. How do ordinary people manage?» [3, p. 48]. This is the starting point of her becoming meditative of her real ex-subjects' struggle through their lives feeling permanent need for money and social support. Living in Hell Close as an ordinary person she was wondering how people survive in this world.

The Queen also had to face health problems. When in need of medical care, she had to wait for 5 hours to be examined. She was shell-shocked when the doctor said that it was normal: "The queen sank back onto the hospital trolley and closed her eyes tightly against the prickling of tears gathering behind the lids. She must control herself at all costs» [3, p. 51]. Despite all the hardships that came in the way of the Queen she is described as a strong-willed person who tries to survive in these circumstances. Of course, she complained about the lack of money and worried about her son Charles being behind bars, but she was the only one who pulled herself together and tried to do something useful for her family, especially for her husband. During their life in the Hell Close the Queen felt quite lonely because she didn't get any support from him. S. Townsend deliberately describes Philipp as a whiny, arrogant and self-centered man who is outshined by a business-like, optimistic royal spouse «Before the election he had appeared to be a vigorous man, immaculately dressed, with a healthy pink complexion and an arrogant bearing. But now he is the broken wreck» $[3$, p. 60].

However, going through all these physical difficulties the Queen find metaphysical freedom that made her psychologically relaxed: "What must it feel like to open one's mouth and scream? The Queen stood over the washing-up bowl and gave a tiny, experimental scream. She tried again, «Aaaaaaaarggh!!!». Her throat opened wide and the Queen could feel the scream travel up her lungs, overflow her windpipe and roar out of her mouth like a British lion!» [3, p. 100]. That yell is the symbolic but at the same time colourful way of pinpointing the ruining of the stereotype of the Queen's being constantly reserved and well self-controlled.

So, the narration under analysis created by $\mathrm{S}$. Townsend is a perfect example of occasional methods invented by the author to break the long lasting stereotypes communicants have of the ruling monarch. With such an objective, the writer finds it possible to either change the dwelling conditions - decreasing the comfort level to its minimum, the personal well-being or even resorts to contrast aggravated by colorful antithesis that can be seen in the collaboration the ex-royal has with her neighbors. S. Townsend having a whip-crack style manages to describe within a narrative framework a whole chain of psychological and physical processes' evolution taking place in the mind and life of a wellknown representative of the ruling royal family, thus contributing to al- 
ternation and at times ruining of the rooted stereotypes.

\section{Bibliography}

1. Бетанова Д. А. Стереотипы и их роль в процессе межкультурной коммуникации // Актуальные проблемы гуманитарных и естественных наук. - 2011. № 4. - C. 390-395.

2. Леонтьев А. А., Тарасов Е. Ф. Национально-культурная специфика речевого поведения. - М. : Наука. 1977.

3. Townsend S. The Queen and I. - London : Penguin Books, 2012. - 267 p.

\section{Bibliography}

1. Betanova D. A. Stereotipy i ih rol' v processe mezhkul'turnoj kommunikacii // Aktual'nye problemy gumanitarnyh i estestvennyh nauk. - 2011. - № 4. S. 390-395.

2. Leont'ev A. A., Tarasov E. F. Nacional'no-kul'turnaja specifika rechevogo povedenija. - M. : Nauka. 1977.

3. Townsend S. The Queen and I. - London : Penguin Books, 2012. - 267 p.

(C) Dzyubenko A.I., Strezeva Ya. A., 2017. 